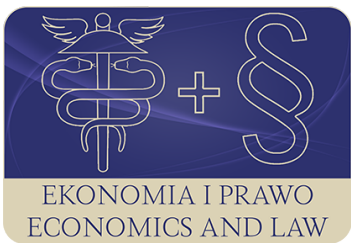

EKONOMIA I PRAWO. ECONOMICS AND LAW

Volume 20, Issue 2, June 2021

p-ISSN 1898-2255, e-ISSN 2392-1625

www.economicsandlaw.pl

ORIGINAL ARTICLE

received 25.08.2020; revised 20.06.2021; accepted 30.06.2021

Citation: Pieloch-Babiarz, A. (2021). An impact of the first and second-largest shareholders on a catering effect: evidence from Poland. Ekonomia i Prawo. Economics and Law, 20(2), 353-366. https://doi.org/10.12775/EiP.2021.021.

\title{
An impact of the first and second- largest shareholders on a catering effect: evidence from Poland
}

\author{
ALEKSANDRA PIELOCH-BABIARZ \\ University of Lodz, Faculty of Economics and Sociology, Department of International Finance \\ and Investments, ul. Rewolucji 1905 r. 41, 90-214 Lodz, Poland \\ $\square$ aleksandra.pieloch@uni.lodz.pl \\ (D) orcid.org/0000-0001-7885-1284
}

\begin{abstract}
Motivation: Dividend pay-out is a frequently undertaken research issue. However, there is no study on the impact of concentrated ownership on adjustment of dividend amount to investor sentiment for pay-outs. The paper contribute to the literature by filling the research gap regarding the catering effect in the context of principal-principal agency con-

flict and type II agency costs, monitoring hypothesis and expropriation hypothesis.

Aim: The aim of the article is to investigate an impact of the first and second-largest shareholders on an adjustment of dividend pay-outs to investor sentiment for dividends.

To achieve the aim, two hypotheses have been formulated, i.e. Hl: if the first-largest shareholder is a strategic investor, a catering effect weakens; H2: an existence of significant second-largest shareholder moderates the extent to which companies cater to investor sentiment for dividends.

Results: There are three main finding: 1) the number of shares held by the first-largest shareholder is lower in dividend payers, while the number of shares held by the second-largest shareholder is lower in dividend non-payers; 2) listed companies from electromechanical industry sector cater to investor sentiment for dividends; 3) both research hypotheses have not been satisfied.
\end{abstract}

Keywords: dividend pay-out; catering theory of dividends; catering effect; agency theory; ownership concentration

JEL: G35; G41; M21 


\section{Introduction}

The aim of the article is to investigate an impact of the first and second-largest shareholders on an adjustment of dividend pay-outs to investor sentiment for dividends. This objective is important for three main reasons. Firstly, it asserts agency-cost explanation of dividend pay-out in the context of behavioural considerations. The paper is relevant to the behavioural approach presented by the catering theory of dividends which was introduced by Baker \& Wurgler (2004a, pp. 1125-1165; 2004b, pp. 27l-288). In this theory, it is assumed that investors behave irrationally, i.e. they make investment decisions basing only on dividend pay-outs. In turn, managers act in rational way, i.e. they analyse investor's preferences and observe changes in the market share prices. Basing on that, they make decisions regarding dividend. They pay it out when the capital market values dividend payers higher than non-payers. This is the case when the so-called dividend premium, understood as a difference between the average price-to-book value of dividend payers and non-payers (compare Eije \& Megginson, 2008, p. 363; Gajdka, 2013, p. 152; Kowerski, 2011, p. 91; Neves, 2014, p. 40), is positive. Secondly, our research has been conducted to fill the research gap regarding the lack of studies in the field of an impact of the largest shareholders on the catering effect of dividends. The catering effect is understood in this paper, in accordance with the definition given by Li \& Lie (2006, p. 294), as an increase in the amount of dividend pay-out in the years of high dividend premium. Thirdly, the empirical results of research on an impact of the largest shareholders on an adjustment of dividend pay-outs to investor sentiment for dividends demonstrate important implications for stakeholders, both insiders and outsiders. It is because the dividend policy has an impact on company's investment opportunities, influences the market value of company, as well as creates the shareholder's value (DeAngelo \& DeAngelo, 2006, pp. 293-315).

To achieve the aim of the paper, we posit the following hypotheses:

- Hl: if the first-largest shareholder is a strategic investor ${ }^{1}$, the catering effect for dividends weakens;

- H2: an existence of significant second-largest shareholder ${ }^{2}$ moderates the extent to which companies cater to investor sentiment for dividends.

These hypotheses have been formulated basing on two approaches regarding the activities and obligations of the largest shareholders, i.e. the expropriation hypothesis and monitoring hypothesis. Taking into account the expropriation hypothesis (Fama \& Jensen, 1983, pp. 301-325; Neves, 2014, p. 36), we assume that in the companies in which the first-largest shareholder holds at least $50 \%$ of shares (i.e. that shareholder has a great impact on the decision-making process), there is a tendency to extract private benefits of control at the expense of minority shareholders (Shleifer \& Vishny, 1997, pp. 737-783). As a result,

${ }^{1}$ Strategic investor is understood as an owner holding at least $50 \%$ of shares.

2 Significant second-largest shareholder is understood as a significant investor, i.e. a shareholder that holds at least $20 \%$ of shares. 
a decrease in the dividend pay-out is usually observed (Gugler \& Yurtoglu, 2003, p. 731; Khan, 2006, p. 172). Therefore, we suspect that such companies take less account of investor sentiment for dividends, so catering effect weakens. In turn, basing on the monitoring hypothesis, we adopt an assumption that an obligation of the largest shareholders is to monitor the activities of managers in order to protect the interests of minority shareholders (Bena \& Hanousek, 2008, p. 107). Assuming that if the first-largest shareholder acts to extract a rent at the expense of minority shareholders, and there is no collusion between two largest shareholders (see Neves, 2014, p. 42), the second-largest shareholder is expected to provide a balance in the ownership structure, monitor activities of the first-largest shareholder (Aluchna et al., 2019, p. 231) and act in the interest of minority shareholders. Therefore, we expect that a negative impact of the first-largest shareholder on the catering effect of dividends is mitigated by the activities of the second-largest shareholder.

The remainder of this paper is organized as follows. Section 2 contains a literature review. Section 3 describes the methodology. Section 4 presents the research results. Section 5 summarizes and concludes.

\section{Literature review}

The dividend policy has been a subject of many scientific studies. Lintner (1956) and Miller \& Modigiliani (1961) are among the first authors conducting the research on this issue. Although dividend policy has remained the subject of interest for decades, the dividend puzzle has not been solved. Therefore, there are many approaches and theoretical frameworks attempting to explain this issue. Among them, there are these regarding the clientele effect (Black \& Scholes, 1974), signalling theory (Bhattacharya, 1979; John \& Williams, 1985) and agency conflicts (Jensen \& Meckling, 1976).

The clientele effect is understood as a phenomenon of attracting by the company these investors that are interested in a specific dividend policy. According to the literature, there are two types of the clientele effect, i.e. the tax and dividend clientele effect. Considering different taxation, the tax clientele effect should be recalled. In that case, dividend and capital gains can be viewed as the tools satisfying various needs and expectations of heterogeneous tax clienteles (Djebali \& Belanes, 2015) and attracting different investors, i.e. these that prefer minimizing tax burdens and these that prefer minimizing transaction costs (Damodaran, 2007, p. 1041-1042; De Angelo et al, 2008, p. 202). Due to diverse taxation policy, some investors can perceive dividend as less valuable than capital gains which may result, among others, in replacing dividends by stock repurchases (Skinner, 2008, p. 582). Whereas, considering different types of dividend pay-outs, the dividend clientele effect should be recalled. This effect refers to investing the capital in these companies that conduct such dividend policy that is attractive for stock market investors in terms of the stability and regularity of dividend pay-outs, as well as the amount or type of dividends. 
Furthermore, dividend can be perceived as a financial tool used by the company to communicate information to the capital market (Batabyal \& Robinson, 2017, p. 158) and to mitigate the information asymmetry between managers and investors (Harakeh et al., 2019, p. 82). Managers adjust dividend pay-outs in order to signal expected future results of the company, as well as its intrinsic value. The signaling effect is particularly strong in the case of changes in dividend policy. A dividend initiation or an increase of dividend pay-out is usually perceived as a positive signal sent from the company to investors, while a dividend reduction or its omission is usually negatively perceived by the market (Pieloch-Babiarz, 2016, p. 99).

In turn, agency theory (Jensen \& Meckling, 1976, pp. 305-360) appeared in connection with the separation of ownership from management and divergence of goals of principals (shareholders) and agents (managers). Both types of stakeholders attempt to achieve their own goals, i.e. principals expect a maximization of investing income in the form of capital gains or dividends, while agents try to maximize their benefits such as job security and job retention, salary, prestige, job position and great power. In other words, managers are often imperfect agents that do not focus on achieving principals' goals, so a principal-agent agency conflict arises. As a result, principals have to monitor managers (Gugler \& Yurtoglu, 2003, pp. 731-758), which generates type I agency costs (Aluchna et al., 2019, p. 230). The monitoring role of principals is particularly emphasized in the case of emerging markets and civil-law systems which are characterised by insufficient investors protection, concentrated ownership and lower transparency standards (Aluchna et al., 2019, p. 228; Basse, 2013, p. 262). Type I agency costs can be reduced by paying out dividend which requires the company to raise the capital from the capital market (Easterbrook, 1984, pp. 650-659) and is a subject to capital market assessment, control and discipline (Michaely \& Roberts, 2012, pp. 712-746). Moreover, agency cost reduction can also occur through the appropriate shaping of ownership structure (Tripathi, 2019, p. 20). Holding some shares by managers should lead to convergence effect and alignment of interest of principals and agents. However, Shleifer \& Vishny (1997, pp. 461-488) proved that at lower levels of managerial ownership, agents identify themselves with minority shareholders, and their goals become convergent. It is manifested, among others, in paying out dividends. However, when the concentration of managerial ownership increases, agents start to act like large shareholders and try to achieve private benefits of control at the expense of minority shareholders. In that case, the expropriation of minority shareholders, rent extraction, tunnelling and self-dealing are observed in the company (Battowski, 2017, p. 30). Principal-principal agency conflict ${ }^{3}$ appear, and type II agency cost are generated. As a result of large shareholders' entrenchment, dividend is paid out sparsely, and its amount decreases (Gugler \& Yurtoglu, 2003, p. 731). Minority shareholders do not have enough legal

${ }^{3}$ Principal-principal agency conflict is understood as a conflict between large shareholders (controlling owners) and minority shareholders (Gugler \& Yurtoglu, 2003, p. 731). 
power to force large shareholders to pay out dividend (Aluchna et al., 2019, p. 230). Therefore, the role of the second-largest shareholder is crucial in that case. Assuming that there is no collusion between the largest shareholders, the second-largest shareholder is expected to act in the interest of minority shareholders by monitoring the managers (Neves, 2014, p. 41), controlling the first-largest shareholder and mitigate the negative impact of their activities (Aluchna et al., 2019, p. 231). However, results of research on this issue remain mixed. There are some research proving a negative influence of the first-largest shareholder on dividend pay-out, and positive impact exerted by the second-largest shareholder (see Bena \& Hanousek, 2008, pp. 106-130; Gugler \& Yurtoglu, 2003, pp. 731-758; Neves, 2014, p. 48). The opposite results have been achieved by López-Iturriaga \& Santana-Martin (2015, pp. 519-533). Furthermore, that research issue has been extended by Neves (2014, pp. 35-58) who has conducted the study on an impact of the ownership structure on company's propensity to adjust pay-outs to investor sentiment for dividends. This author proves a negative correlation between the number of shares held by the first-largest shareholder and catering effect, and shows that an existence of the second-largest shareholder moderates the extent to which companies cater to investor sentiment for dividends. It should be noticed that Neves (2014) research is, so far, the only study recognizing that issue. That research is based on 487 companies running business in the years 1990-2003 in nine West European countries. Due to the fact that such research has not been conducted on Polish market, there is a need to carry it out.

\section{Methods}

At the beginning, the research sample consisted of Polish publicly traded companies from electromechanical industry sector, which were listed on the main market of the Warsaw Stock Exchange in the period between 2009-20204. A decision of choosing that sector is dictated by its stability, maturity, large size and great number of dividend pay-outs, which allows us to conduct a longitudinal studies. Furthermore, this sector is characterized by a relatively low average number of shares held by the first-largest shareholder ${ }^{5}$, which is important from the point of view of catering effect, because the lower an ownership concentration, the more attention is paid to the interests of minority shareholders. In addition, focusing only on one sector enables us to avoid the issue of sample heterogeneity. Moreover, the adopted research assumptions made it necessary to include only years with a positive dividend premium. Due to the fact that in the last two years dividend premium was negative and equal to -0.937

4 To conduct the studies according to assumptions made, we collected data for the period 2007-2020.

${ }^{5}$ In the last year of the study, an average share of the first-largest shareholder in non-financial companies listed on the WSE was at $42.56 \%$, while in the electromechanical industry sector it was at $37,78 \%$. 
and -0.054 , it was necessary to exclude these years from the research period. As a result, the final research sample covers the period 2009-2018 and consists of 270 firm-year observations ${ }^{6}$. All financial and market data has been collected from the Notoria Service (2021) database and Stock Market Yearbooks, while data on the ownership structure has been hand-collected from year reports placed on the companies' websites. To conduct an analysis we use Statistica and Gretl.

To test the hypotheses and investigate the impact of the first and second-largest shareholders on an adjustment of pay-outs to investor sentiment for dividends, the balanced panel is analysed. We use random effects model instead of the pool OLS or the fixed effects models basing our decision on the BreuschPagan test and the Hausman test (Stawasz-Grabowska, Grabowski, 2018, p. 74-75).

In order to verify the hypotheses, two regression models have been estimated. First, to investigate whether catering effect weakens if the first-largest shareholder is a strategic investor, model 1 has been proposed:

$$
\begin{aligned}
& \operatorname{DivPay}_{i, t}=\gamma_{0}+\text { Cater }_{i, t-2}\left(\gamma_{1}+\text { FirstLS }_{i, t-1}\right)+\gamma_{2} \text { Profit }_{i, t-1}+ \\
& +\gamma_{3} \text { Liquid }_{i, t-1}+\gamma_{4} \text { Debt }_{i, t-1}+\gamma_{5} \text { Age }_{i, t-1}+\varepsilon_{i, t},
\end{aligned}
$$

where:

DivPay $_{i, t}$ - a dividend pay-out ratio of $i$-th company in year $t$;

Cater $_{i, t-2}$ - a proxy for catering effect calculated using formula for dividend premium proposed by Gajdka (2013, p. 152);

First $L S_{i, t-1}$ - a dummy variable that takes value 1 if the largest shareholder is a strategic investor (i.e. holds not less than $50 \%$ of shares), and 0 otherwise. In this way, the coefficient of the catering variable is $\gamma_{1}$ for companies without strategic investor (since FirstLS takes value 0), and $\gamma_{1}+\alpha_{1}$ otherwise. In accordance with the literature review and the hypothesis $\mathrm{Hl}$, the coefficient $\gamma_{1}+\alpha_{1}$ is expected to be positive and statistically significant $^{7}$, however lower than $\gamma_{1}$;

control variables:

Profit i,t-1 $_{\text {- }}$ a return on assets of $i$-th company in year $t-1$;

Liquid $_{i, t-1}$ - a current ratio of $i$-th company in year $t-1$;

Debt $t_{i, t-1}$ - a debt ratio of $i$-th company in year $t-1$;

Age $_{i, t-1}$ - an age of $i$-th company in year $t-1$;

$\varepsilon_{i, t}-$ a random component.

Second, in order to study an extend to which companies cater to their investor's sentiment for dividend regarding to the number of shares held by the second-largest shareholder, model 2 has been estimated:

${ }^{6}$ In 2018, the analyzed sector consisted of 32 companies of which 5 had to be excluded from further research due to missing data.

7 If coefficients of dummy variables are significant, a linear restriction test is needed (null hypothesis $\mathrm{H}_{0}$ : the sum of coefficients is equal to 0 ). 


$$
\begin{aligned}
& \text { DivPay }_{i, t}=\gamma_{0}+\text { Cater }_{i, t-2}\left(\gamma_{1}+\alpha_{1} \text { FirstLS }_{i, t-1}\right)+\beta_{1} \text { SecondLS }_{i, t-1}+ \\
& +\gamma_{2} \text { Profit }_{i, t-1}+\gamma_{3} \text { Liquid }_{i, t-1}+\gamma_{4} \text { Debt }_{i, t-1}+\gamma_{5} \text { Age }_{i, t-1}+\varepsilon_{i, t},
\end{aligned}
$$

where:

SecondLS $S_{i, t-1}$ - a dummy variable that takes value 1 if the second-largest shareholder is a significant investor (i.e. holds at least $20 \%$ of shares but less than $50 \%$ of shares), and 0 otherwise; and the other designations as above.

In this way, the coefficient of the catering variable is $\gamma_{1}$ for companies in which the first-largest shareholder is not a strategic investor and the second-largest shareholder is not a significant investor (since FirstLS and SecondLS takes value $0) ; \gamma_{1}+\alpha_{1}$ for companies in which the first-largest shareholder is a strategic investor and at the same time the second-largest shareholder is not a significant investor (since First $L S=0$ and Second $L=0$ ); $\gamma_{1}+\beta_{1}$ for companies in which both the first and second-largest shareholders are significant investors (since first $L S=0$ and SecondLS=1); $\gamma_{1}+\alpha_{1}+\beta_{1}$ for companies in which the first-largest shareholder is a strategic investor and the second-largest shareholder is a significant investor (since FirstLS and SecondLS takes value 1). In accordance with the literature review and the hypotheses, given sums of coefficients are expected to be positive and statistically significant, in particular $\gamma_{1}+\alpha_{1}$ is expected to be lower than $\gamma_{1}$ (since we assume that strategic investors extract rent at the expense of minority shareholders); $\gamma_{1}+\beta_{1}$ is expected to be higher than $\gamma_{1}$ (since we assume that it is easier for the second-largest shareholder to monitor the first-largest shareholder when they are not strategic investors and take care of minority shareholders catering to investor sentiment for dividends); $\gamma_{1}+\alpha_{1}+\beta_{1}$ is expected to be at a similar level as $\gamma_{1}$ (since we assume that - based on expropriation hypothesis and monitoring hypothesis - the rent extraction effect and monitoring effect cancel each other out when there are both the strategic and significant investors in a company.

\section{Results}

Table 1 presents the characteristics of analysed companies according to the first and second-largest shareholders broken down into dividend payers and non-payers. The results show that the first-largest shareholder holds, on average, 38.14\% of shares, while the second one holds $13.39 \%$. The median is at $37.60 \%$ and $11 \%$, respectively. Moreover, the minimum number of shares of the first-largest shareholder is at $4.50 \%$, while the maximum one is at $92 \%$. Considering the second-largest shareholder, these values are at $0 \%$ and $40.70 \%$, respectively. Comparing dividend payers with non-payers, it should be pointed out that dividend is paid out by these companies in which the first-largest shareholder holds relatively fewer shares. In dividend payers, the average ownership of the first-largest shareholder is at $35.33 \%$, while in non-payers it is at $40.51 \%$.That result 
is consistent with the alignment of interest and entrenchment effect. In other words, the more shares is held by the first-largest shareholder, the less eager they are to meet other shareholders' expectations and to pay out dividend. We can suspect that the first-largest shareholder attempts to achieve financial benefits at the expense of minority shareholders. Conversely, the number of shares held by the second-largest shareholder is higher in dividend payers (mean is $15.93 \%$ and $11.21 \%$, respectively; median is $11.21 \%$ and $10 \%$, respectively). That results are consistent with the monitoring hypothesis and may suggest that the second-largest shareholder monitors both the managers and the first-largest shareholder, taking care of the interests of minority shareholders, including dividend pay-outs.

Table 2 reports the coefficients of pairwise correlation between the variables. A significant correlation between dependent and independent variables are observed. The highest correlation (positive and statistically significant at $1 \%$ ) is observed for DivPay and Cater $\left(r_{y x}=0.69\right)$, which is consistent with our assumptions and indicates that dividend policy is adapted to investor sentiment for dividends. In turn, negative correlation is observed for DivPay and Debt $\left(r_{y x}=-0.32\right)$, which is in line with the literature and our expectations. Considering a correlation between independent variables, it should be noticed that independent variables have been chosen in such a way that the correlation between them would not exceed $|0.7|$. The strongest correlation is observed between Liquid and Debt $\left(r_{y x}=-0.65\right)$.

Table 3 shows the estimation results of two models used for testing the implications of the catering theory of dividends by means of some ownership characteristics, i.e. the number of shares held by two largest shareholders. As shown, a coefficient at Cater is positive and statistically significant at $1 \%$ (in model 1 it is at 0.62 , and in model 2 it is at 0.61 ), which confirms an existence of catering effect and means that analysed companies take into account the preferences of investors and pay out higher dividend when they expect it. These findings are in line with the results of Li \& Lie (2006, pp. 293-308). These authors proved an existence of positive correlation between catering and dividend pay-out ratio, which means that companies cater more to investor sentiment for dividends if shareholders expect it.

Focusing on the estimation results of model 1 , which is used to investigate whether there are any changes in catering effect if the first-largest shareholder is a strategic investor (i.e. holds at least $50 \%$ of shares), it can be noticed that, in that case, a positive effect on dividends is slightly weaker $\left(\gamma_{1}+\alpha_{1}=0.60\right)$. However, it must be pointed out that a coefficient at Cater-FirstLS $\left(\alpha_{1}=-0.02\right)$ is not statistically significant at accepted levels of significance. Thus, the hypothesis $\mathrm{Hl}$ is not supported.

Regarding model 2, which investigates an extend to which companies cater to investor sentiment for dividends regarding to the number of shares held by the two largest shareholder, a coefficient at Cater-FirstLS is negative $\left(\alpha_{1}=-0.02\right)$, while a coefficient at Cater-SecondLS is positive $\left(\beta_{1}=0.01\right)$, which may indicate 
that the presence of strategic investor contributes significantly to abolishing a negative impact of the first-largest shareholder on catering, and catering effect is slightly stronger $\left(\gamma_{1}+\alpha_{1}+\beta_{1}=0.60>\gamma_{1}+\alpha_{1}=0.59\right)$. However, received coefficients are not statistically significant at the given significance levels. Therefore, the hypothesis $\mathrm{H} 2$ is not supported.

In addition, the coefficients at control variables are in line with our expectations, i.e. return on assets, current ratio and age are positive and statistically significant in both models $(0.67,0.04$ and 0.01 , respectively), while a coefficient at debt ratio is positive but statistically insignificant.

\section{Conclusion}

The paper attempts to contribute to the catering theory of dividends in the context of some ownership characteristics, i.e. the number of shares held by two largest shareholders. The research results show that the number of shares held by the first-largest shareholder is lower for dividend payers, while the number of shares held by the second-largest shareholder is lower for dividend non-payers. These results are consistent with the entrenchment effect and monitoring hypothesis which indicate that the first-largest shareholder strives to achieve financial benefits at the expense of other shareholders, while the second-largest shareholder monitors managers and takes care of minority shareholder's interest. However, further research are required to confirm that. The main finding of the research is that analysed companies cater to investor sentiment for dividends but in-depth research is needed in order to draw conclusions concerning an influence of the largest shareholders on catering effect. Therefore, two research hypotheses are formulated but both of them (i.e. $\mathrm{Hl}$ and $\mathrm{H} 2$ ) are not satisfied.

It is worth to notice that our research is not free of limitations. First of all, it is carried out among Polish publicly traded companies and applies to one sector on the WSE. Therefore, the study should be considered as preliminary one. It is proposed to extend the research to companies from other sectors and compare them with companies from other countries. Moreover, we recommend to use different methods of dividend premium calculation (not only those calculated at the market level but also those determined at the company's level), as well as to investigate an impact of other shareholders (managers, institutional investors, State Treasury, etc.) on disposition of companies to adjust pay-outs to investor sentiment for dividends.

\section{References}

Aluchna, M., Berent, T., \& Kamiński, B. (2019). Dividend payouts and shareholder structure: evidence from the Warsaw Stock Exchange. Eastern European Economics, 57(3), 227-250. https://doi.org/10.1080/00128775.2019. 1568196. 
Baker, M., \& Wurgler, J. (2004a). A catering theory of dividends. The Journal of Finance, 59(3), 1125-1165. https://doi. org/10.1111/j.1540-6261.2004.00658.x.

Baker, M., \& Wurgler, J. (2004b). Appearing and disappearing dividends: the link to catering incentives. Journal of Financial Economics, 73(2), 271288. https://doi.org/10.1016/j.jfineco.2003.08.001.

Bałtowski, M. (2017). Więcej władzy niż własności: Skarb Państwa jako szczególny inwestor na GPW w Warszawie. Economic Studies, 1(92), 27-45.

Basse, T. (2013). Effects of inflation on dividend payments: an empirical study of public companies in Hungary. International Journal of Management, 30(1), 262-271.

Batabyal, S., \& Robinson, R. (2017). Capital change and stability when dividends convey signals. Quarterly Review of Economics \& Finance, 65, 158-167. https://doi.org/10.1016/j.qref.2016.08.009.

Bena, J., \& Hanousek, J. (2008). Rent extraction by large shareholders: evidence using dividend policy in the Czech Republic. Czech Journal of Economics and Finance, 58(3-4), 106-130.

Bhattacharya, S. (1979). Imperfect information, dividend policy, and "the bird in the hand" fallacy. The Bell Journal of Economics, 10(1), 259-270. https:// doi.org/10.2307/3003330.

Black, F., \& Scholes, M. (1974). The effects of dividend policy on common stock prices and returns. Journal of Financial Economics, 1(1), 1-22. https://doi. org/10.1016/0304-405X(74)90006-3.

Damodaran, A. (2007). Finanse korporacyjne: teoria i praktyka. Helion.

DeAngelo, H., \& DeAngelo, L. (2006). The irrelevance of the MM dividend irrelevance theorem. Journal of Financial Economics, 79(2), 293-315. https:// doi.org/10.1086/261385.

Djebali, R., \& Belanes, A. (2015). On the impact of family versus institutional blockholders on dividend policy. Journal of Applied Business Research, 31(4), 1329-1342. https://doi.org/10.19030/jabr.v3li4.9320.

Easterbrook, F.H. (1984). Two agency-cost explanations of dividends. The American Economic Review, 74(4), 650-659.

Eije, H., \& Megginson, W.E. (2008). Dividends and share repurchases in the European Union. Journal of Financial Economics, 89(2), 347-374. https://doi.org/10.1016/j.jfineco.2007.11.002.

Fama, E.F., \& Jensen, M.C. (1983). Separation of ownership and control. Journal of Law and Economics, 26(2), 301-325. https://doi.org/10.1086/467037.

Gajdka, J. (2013). Cateringowe podejście do polityki dywidendy w warunkach polskiego rynku kapitałowego. Zarządzanie i Finanse, 2(4), 153-165.

Gugler, K., \& Yurtoglu, B. (2003). Corporate governance and dividend pay-out policy in Germany. European Economic Review, 47(4), 731-758. https://doi. org/10.1016/s0014-2921(02)00291-x. 
Harakeh, M., Lee, E., \& Walker, M. (2019). The effect of information shocks on dividend payout and dividend value relevance. International Review of Financial Analysis, 61, 82-96. https://doi.org/10.1016/j.irfa.2018.10.009.

Jensen, M., \& Meckling, W. (1976). Theory of the firm: managerial behavior, agency costs and ownership structure. The Journal of Financial Economics, 3(4), 305-360. https://doi.org/10.1016/0304-405X(76)90026-X.

John, K., \& Williams, J. (1985). Dividend, dilution and taxes: a signaling equilibrium. The Journal of Finance, 40(4), 1053-1070. https://doi. org $/ 10.2307 / 2328394$.

Khan, T. (2006). Company dividends and ownership structure: evidence from UK panel data. Economic Journal, 116(510), 172-189. https://doi. org/10.1111/j.1468-0297.2006.01082.x.

Kowerski, M. (2011). Ekonomiczne uwarunkowania decyzji o wyptatach dywidend przez spótki publiczne. Konsorcjum Akademickie.

Li, W., \& Lie, E. (2006). Dividend changes and catering incentives. Journal of Financial Economics, 80(2), 293-308. https://doi.org/10.1016/j. jfineco.2005.03.005.

Lintner, J. (1956). Distribution of income of corporations among dividends, retained earnings and taxes. American Economic Review, 46(2), 97-113.

López-Iturriaga, F., \& Santana-Martín, D. (2015). Do shareholder coalitions modify the dominant owner's control: the impact on dividend policy. Corporate Governance: An International Review, 23(6), 519-533. https://doi. org/10.1111/corg.12126.

Michaely, R., \& Roberts, M.R. (2012). Corporate dividend policies: lessons from private firms. The Review of Financial Studies, 25(3), 711-746. https:// doi.org/10.1093/rfs/hhr108.

Miller, M., \& Modigiliani, F. (1961). Dividend policy, growth and the valuation of shares. Journal of Business, 34(4), 411-433. https://doi. org/10.1086/294442.

Neves, E.D. (2014). Ownership structure and investor's sentiment for dividend. International Journal of Financial Research, 5(2), 35-58. https://doi. org/10.5430/ijfr.v5n2p35.

Notoria Serwis. (2021). Retrieved 15.09.2021 from https://ir.notoria.pl.

Pieloch-Babiarz, A. (2016). Reakcja rynku kapitałowego na wypłatę dywidendy inicjalnej w świetle cateringowej teorii dywidendy. Studia Ekonomiczne, 263, 88-102.

Shleifer, A., \& Vishny, R. (1997). A survey of corporate governance. Journal of Finance, 52(2), 737-783.

Skinner, D. (2008). The evolving relation between earnings, dividends and stock repurchases. Journal of Financial Economics, 87(3), 582-609. https://doi. org/10.1016/j.jfineco.2007.05.003.

Stawasz-Grabowska, E., \& Grabowski, W. (2018). Rynek obligacji skarbowych $w$ strefie euro w okresie kryzysu. CeDeWu. 
Tripathi, V. (2019). Agency theory, ownership structure and capital structure: an empirical investigation in the Indian automobile industry. Asia-Pacific Management Accounting Journal, 14(2), 1-22. http://dx.doi.org/10.24191/ apmaj.vl4i2.766.

\section{Acknowledgements}

Author contributions: author has given an approval to the final version of the article.

Funding: this research was fully funded by the University of Lodz. 


\section{Appendix}

\section{Table 1.}

Characteristics of the research group according to the number of shares held by the first and second-largest shareholders (\%)

\begin{tabular}{|c|c|c|c|c|c|}
\hline Specification & Mean & St. dev. & Min. & Median & Max. \\
\hline \multicolumn{6}{|c|}{ panel A : total sample $(\mathrm{N}=270)$} \\
\hline first & 38.14 & 20.69 & 4.50 & 37.60 & 92.00 \\
\hline second & 13.39 & 9.28 & 0.00 & 11.00 & 40.70 \\
\hline \multicolumn{6}{|c|}{ panel B: dividend payers $(\mathrm{N}=122)$} \\
\hline first & 35.33 & 18.43 & 10.43 & 37.60 & 78.70 \\
\hline second & 15.93 & 10.01 & 5.00 & 11.21 & 40.70 \\
\hline \multicolumn{6}{|c|}{ panel C: dividend non-payers $(\mathrm{N}=148)$} \\
\hline first & 40.51 & 22.22 & 4.50 & 37.60 & 92.00 \\
\hline second & 11.21 & 8.02 & 0.00 & 10.00 & 37.50 \\
\hline
\end{tabular}

Source: Own preparation based on companies' annual reports.

Table 2.

Pearson correlation matrix

\begin{tabular}{|c|c|c|c|c|c|c|c|c|}
\hline Specification & DivPay & Cater & Cater-FirstLS & Cater-SecondLS & Profit & Liquid & Debt & Age \\
\hline DivPay & 1.00 & & & & & & & \\
\hline Cater & $0.69^{* * *}$ & 1.00 & & & & & & \\
\hline Cater-FirstLS & $0.28^{* * *}$ & $0.43^{* * *}$ & 1.00 & & & & & \\
\hline Cater-SecondLS & $0.40^{* * *}$ & $0.54^{* * *}$ & $0.12^{*}$ & 1.00 & & & & \\
\hline Profit & $0.36^{* * *}$ & $0.37^{* * *}$ & -0.01 & $0.13^{* *}$ & 1.00 & & & \\
\hline Liquid & $0.42^{* * *}$ & $0.42^{* * *}$ & 0.06 & $0.20^{* * *}$ & $0.34^{* * *}$ & 1.00 & & \\
\hline Debt & $-0.32^{* * *}$ & $-0.35^{* * *}$ & -0.01 & $-0.19^{* * *}$ & $-0.43^{* * *}$ & $-0.65^{* * *}$ & 1.00 & \\
\hline Age & $0,24^{* * *}$ & $0.25^{* * *}$ & $0.18^{* * *}$ & $0.18^{* * *}$ & 0.02 & -0.06 & $0.13^{*}$ & 1.00 \\
\hline
\end{tabular}

Notes:

${ }^{*},{ }^{* *},{ }^{* * *}$ represent statistical significance at the $10 \%, 5 \%$, and $1 \%$ levels.

Source: Own preparation based on Notoria Serwis (2021) and companies' annual reports. 
Table 3.

Estimation results of random effects model

\begin{tabular}{lcc}
\hline \multicolumn{1}{c}{ Specification } & Model l & Model 2 \\
\hline Intercept & -0.08 & -0.07 \\
Cater & $0.62^{* * *}$ & $0.61^{* * *}$ \\
Cater-FirstLS & -0.02 & -0.02 \\
Cater-SecondLS & & 0.01 \\
Profit & $0.67^{* *}$ & $0.67^{* *}$ \\
Liquid & $0.04^{* *}$ & $0.04^{* *}$ \\
Debt & 0.01 & 0.01 \\
Age & $0.01^{* *}$ & $0.01^{* *}$ \\
\hline Breusch-Pagan; $\chi^{2}(1)$ & 9.18 & 9.15 \\
p-value & 0.00 & 0.00 \\
Hausman; $\chi^{2}(\mathrm{~K})$ & 8.94 & 11.87 \\
$\mathrm{p}$-value & 0.18 & 0.12 \\
\hline
\end{tabular}

Notes:

${ }^{*},{ }^{* *},{ }^{* * *}$ represent statistical significance at the $10 \%, 5 \%$, and $1 \%$ levels.

Source: Own preparation based on Notoria Serwis (2021) and companies' annual reports. 